\title{
Learner Autonomy and Curriculum Delivery in Higher Education: The Case of University of Uyo, Nigeria
}

\author{
Alice E. Udosen ${ }^{1}$ \\ ${ }^{1}$ Department of Curriculum Studies, University of Uyo, Uyo, Nigeria \\ Correspondence: Alice E. Udosen, Department of Curriculum Studies, University of Uyo, Box 4256 Uniuyo \\ P.O., Uyo, Nigeria. Tel: 234-803-566-4356. E-mail: alidosen@yahoo.com
}

Received: November 29, 2013 Accepted: January 23, 2014 Online Published: February 21, 2014

doi:10.5539/ies.v7n3p40

URL: http://dx.doi.org/10.5539/ies.v7n3p40

\begin{abstract}
Nigeria has much hope on her higher education for the production of manpower needs of the nation. And manpower production is a function of the curriculum and its delivery modes which can only be as good as its teachers. It is no gain saying that the traditional methods of curriculum delivery can no longer serve our purpose. Efforts are being made the world over to focus on curriculum delivery modes that build on the recent technological developments and the enriched learning experiences they provide to foster learner autonomy. But the curriculum delivery modes of lecturers in higher education institutions, regarding learner autonomy is not known. This study therefore sought to find out whether the curriculum delivery mode of lecturers in the University of Uyo and their media utilization are such that can foster learner autonomy. Four hundred final year students from four out of the nine faculties were randomly selected and they responded to the questionnaire. Data were analyzed using frequencies, percentages, and one way ANOVA statistics. Results showed that lecturers' delivery modes tended towards teacher-centredness and their media utilization was more of the low level type. Some of them were more of talk and chalk type. Among the recommendations made based on the findings of the study was the need for workshops and seminars to be organized for lecturers to acquaint them of the use of new technologies for effective curriculum delivery to achieve the goals of higher education in Nigeria. Also, lecturers should see themselves as facilitators of learning by adopting learner-centered strategies that would wean the students of their dependence to take charge of their learning and become effective learners that the nation desires.
\end{abstract}

Keywords: curriculum delivery, learner autonomy, higher education and constructivism

\section{Introduction}

Nigeria is one of the developing countries of the world still grappling with political, economic and social challenges. She however hopes in her higher education system for the production of the required manpower to man the various sectors of the economy. But manpower production is affected by a number of factors. These include the curriculum which must be relevant and functional and its delivery mode which again depends on the teachers' competence and resourcefulness; and of course, on the availability and accessibility of modern technological media. In order for higher education to deliver on its mandates, the teaching and learning behaviours of its participants should be scrutinized. In Africa, many countries are repackaging their curriculum and delivery strategies in line with the emerging societal needs. They also have built-in quality mechanism to enable them assess the institutions' attainment of the required developmental goals. Often, it is the product of these institutions that are used as baseline for these assessments. In spite of the efforts to provide relevant curriculum, literature is replete with studies decrying the failure of our higher education system to produce competent manpower for the country especially the teacher education programmes (Falayajo, 2004). Again, research has shown that teaching with information and communication technology (ICT) reduces the input-output time and increases the process time (Manoharan, 2009). The process time is very crucial as it affords learners opportunity to interact with the teachers as well as with fellow students, engaging in activities that promote learning. Such interactions and activities may involve meaningful discussions, brainstorming on issues, demonstrations and search for knowledge using modern media like the computers, and internet facilities and other electronic and print media (Offorma, 2009). A relevant curriculum delivered with the learner at the centre enhances their ability to take control of their learning, enable them to construct meaning and learn skills, 
attitudes, and values that they can use to solve life's problems. Such learners are said to be autonomous because they are actively involved in their learning rather than being passive conformists.

It is worth noting that Nigeria through its appropriate regulatory bodies is providing relevant curriculum at the higher education levels. However, what is not known is whether the curriculum is being delivered in a manner to achieve its goals. That is the focus of this study. The next section examines relevant literature to the study.

\section{Literature Review}

It is pertinent to examine other scholars' views on the major variables of this study, namely; curriculum delivery, learner autonomy and higher education.

\subsection{Curriculum Delivery}

Curriculum delivery is a critical issue in schools because it is a means through which the theorized curriculum is translated into the actual curriculum. It is the instructional phase of the curriculum and is synonymous with curriculum implementation which takes place at the classroom level where teachers try to infuse life into the document plan to achieve its intended goals. Curriculum delivery embodies the strategies, techniques, approaches, methods and resource media which teachers employ to facilitate learning. It is the means of executing the intended desires of the curriculum planners. It also includes the interactions that go on during lesson presentation as well as the assignments and researches which engage the learners actively in the learning process. Curriculum delivery is very critical especially in Nigeria, because a beautifully planned curriculum may fail at the delivery stage due to certain factors. These factors may include teachers' incompetence, unmotivated learners, and lack of resource materials, poor assessment procedures and a host of other factors.

Education is a veritable tool for development. In order to catch up with the wind of development, every nation of the world including Nigeria is re- strategizing and repackaging their educational programmes in line with the current global competitiveness and the demands of the knowledge economy. At the root of achieving the goals of these programmes is the delivery system which must match the realities of the times. It is obvious that the new educational programmes and goals demand a shift in the delivery modes to match the emergent knowledge, attitudes, skills, and technologies so as to produce critical, reflective and functional autonomous learners that can be globally competent to drive the engine of development in their nations.

While curriculum delivery determines the type of manpower production for the nation, it is instructive to note that curriculum delivery can only be as good as the teachers. A cursory look at the excerpt below tells the story of what is on ground regarding teacher quality:

The Constant ASUU strike in Nigerian universities has witnessed a phenomenon of brain drain from the Nigerian Universities. The phenomenon has in turn witnessed the emergence of a "new class" of university teachers in Nigeria. This "new class" comprises teachers who are predominantly unqualified. They are intellectually not motivated and professionally uncommitted. These are the teachers who dictate lecture notes to their students, and thus do not help them to develop enquiry and reflective minds required for individual development of the students and for sustainable national development (Udofot, 2006, p. 15).

The excerpt speaks for itself. Most teachers at higher education level lack professionalism and commitment required in translating the vision of the curriculum into reality. Certainly, this caliber of teachers cannot through their curriculum delivery modes produce the type of independent learners we desire; learners who can think for themselves and take actions that would impact positively on their communities.

It is time we realized that 'traditional methods' of delivering curriculum at higher education can no longer serve our purpose because it is teacher-centred. According to Egbe and Uloh-Bethels (2013), the teacher is the most important person in this approach. Throughout the lesson, he is in charge of the subject matter and the environment and makes decisions about what work is needed and what students should do. It is characterized by rote learning on the part of the students who reproduce what was dictated to them with no effort to go beyond the notes recycled to them by the teacher from year to year (Igbokwe, 2010). This corroborates Obanya's (2007) earlier assertion that teachers still dominate instruction in Nigerian schools. Curriculum delivery at the higher education must keep pace with the general developments in the society. They must build on the recent technological developments and enrich the learning experiences they provide to students (Mishra, 2007). While no one method of delivering the curriculum can be said to be the best, effort must be made to use those that promote greater learner participation in the learning process. In view of this, Manoharan's (2009) categorization of methods at higher education institutions merits our attention. The author grouped teaching methods at that level into 3 thus: 
(1) Presentation strategies of Teaching (PST): Here the teacher does much of talking, explaining, describing, enumerating, narrating, showing and demonstrating in a bid to deliver the content to the large audience. This may go for what we call lecture method which is also referred to as teacher-centered method.

(2) Individualized strategies of learning (ISL): This teaching mode is based on the theory that students learn maximally when they work at their own pace and are "actively involved in performing specific learning tasks, and experience success in learning" (Manoharan, 2009, p. 130). ISL requires self-learning materials like books, audio-taped lessons, TV lessons, Radio lessons, Teleconferencing, Computer Assisted learning, and multimedia modules. Here the teacher acts as a guide helping learners to set their own learning goals in line with the overall vision of the curriculum and choose learning activities congruent with the chosen goals. It is this type of delivery mode that fosters learner autonomy.

(3) Interactive strategies of Teaching (IST): This mode provides opportunities for interaction between teachers and learners, learners with learners and beyond the classroom. The interaction can be mental as in asking and answering questions, discussions and exchange of thoughts. It can be physical as when they work in groups to produce things. The technique used include, role playing, seminar, symposia, colloquium, group work, etc. In all this, the teacher remains the facilitator of learning, directing the learners to pursue worthwhile goals.

Since these modes do not all facilitate learner autonomy it becomes imperative that we find out, which of them do lecturers use in delivering the curriculum meant to produce quality manpower for the economy? This question becomes necessary judging from the observations of Akinmusuru (n.d.) who said: "although most instructors have typically advanced training in specific disciplines, they usually have not had any particular training in the methodology of classroom delivery necessary to achieve maximum learning by students".

In their study investigating the strategies that could promote learner autonomy in English language education curriculum delivery in South-East Nigerian universities, Egbe and Uloh-Bethels (2013) discovered among others that English language curriculum delivery at the moment could not promote autonomy because teachers still dominated class activities while the students depended on the lecturers' notes to pass their examinations. Among the strategies found to promote learner autonomy included, the use of collaborative tasks and seminars.

This is where media utilization readily comes to the rescue because they will allow learners explore knowledge beyond the teacher and the classroom. Media can be electronic or print and can be categorized into low and high. The low media considered in this study consist of audio and video taped lessons, radio and television lessons. These types of media go with the traditional methods of teaching which render the learners passive in the class. The high level media on the other hand, are teleconferencing, computer assisted learning, video conferencing, multimedia modules and web-based learning (Manoharan, 2009). These can connect the learners with the outside world and keep them thinking and re-evaluating their actions based on superior reasons.

\subsection{Higher Education}

Higher education may mean different things to different people. Primarily, it is education given at colleges of education, polytechnics, monotechnics, and universities. Higher education broadens the intellectual powers of the individual within a narrow specialization, but also gives him/her a wider perspective of the world around (Mishra, 2007). Barnett (1992) cited in Mishra (2007) gives four concepts of higher education as:

1) A place that produces qualified human resources for economic growth and development;

2) A place that develops the frontiers of knowledge through research;

3) An efficient management of teaching/learning provisions for improving the quality of teaching;

4) A matter of extending life chances, that is, providing opportunities for the development process of the individuals in the society.

These four concepts can be merged into the three main functions of higher education - teaching, research and community development. Higher education is conceived as a feeder system in all walks of life and so supplies the much needed human resources in management, planning, design, teaching and research. Scientific and technological advancement and economic growth of a country is dependent on her higher education system. In Nigeria, tertiary education is synonymous with higher education. And the roles of University education are subsumed under the goals of tertiary education since University education is part of tertiary education (Udofot, 2006, p. 11). Section 8 of the National Policy on Education (NPE) (2004, p. 36) lists the goals of University education as follows: Contribute to national development through high level relevant manpower training:

a. Develop and inculcate proper values for survival of the individual and society;

b. Develop the intellectual capability of individuals to understand and appreciate their local and external 
environments;

c. Acquire both physical and intellectual skills which will enable individuals to be self-reliant and useful members of the society;

d. Promote and encourage scholarship and community service;

e. Forge and cement national unity;

f. Promote national and international understanding and interaction.

To be able to live up to this responsibility, curriculum delivery at this level must be both student-centred and interactive to create the desired independence in the learners.

Contributing to the debate, Obanya (1999) said that higher education encompasses all organized learning and teaching that are open to mature people for building their knowledge and skills to be able to analyze and search for solutions to life problems. In other words, higher education is provided for mature people and the total package makes provision for learners to maximize its benefits (Osam, 2013).

A recent study by Materu (2007) has shown that tertiary education in Africa generally and Nigeria in particular, plays key roles in building capacity and training professionals to support the Millennium Development Goals (MDGs). As such a new range of competences-adaptability, team work, communication skills and the desire for continual learning are required.

Thus, "tertiary institutions are challenged to adjust their programme structures, curricular teaching and learning methods to adapt to these new demands" (Materu, 2007). The present study examines curriculum delivery at the university level with regards to their potentials in fostering learner autonomy.

\subsection{What Is Learner Autonomy?}

Henri Holec is credited as the father of learner autonomy because he first used the term in 1981 in the field of language learning where the term is very popular (Little, 1991). Other scholars have used the term to suit their own contexts. One fact is evident; that autonomy can be seen either (or both) as a means or an end in education (Wikipedia). The following definitions are given in the literature:

Autonomy is the ability to take charge of one's own learning (Holec, 1981).

Autonomy is essentially a matter of learners' psychological relation to the process and content of learning (Little, 1991).

Autonomy is a situation in which the learner is totally responsible for all the decisions concerned with his/her learning and implementation of those decisions.

Autonomy is recognition of the rights of learners within educational systems. Benson and Voller (1997, p. 2) are of the opinion that autonomy can be used:

(1) For situations in which learners study entirely on their own;

(2) For a set of skills which can be learned and applied in self-directed learning;

(3) For an inborn capability which is suppressed by institutional education;

(4) For the exercise of learners' responsibility for their own learning;

(5) For the right of learners to determine the direction of their own learning.

In the education parlance, the term learner autonomy is seen as independence in learning where the learner can acquire skills for life-long learning. This independence in learning is what every institution aspires to achieve especially at higher levels of education.

Autonomy can also be seen as a social process towards the redistribution of power to the construction of knowledge and the roles of participants in the learning process. Emphasis has been on the role of learners in the teaching/learning process. It has been recognized that learning is the responsibility of the learner, no one can learn for him/her. This power shift from teacher centredness to learner-centredness as an approach derives from decades of a series of theories and discoveries which have led to changes in the curriculum. It has been established that learners learn better where more power is given to them in a teaching/learning process as against the age old traditional classroom where power was rested solely on the teacher, and the learner, a passive recipient of knowledge from the "super teacher".

Years of theories, practice and researches have revealed that the learner has the capacity for detachment, critical reflection, decision- making and independent action (Little, 1991, p. 4). Thus, autonomous learners are expected 
to assume responsibility for, and take charge of their own learning by availing themselves of those opportunities held out in the web platforms which engage the attention of learners outside the classroom.

Learner autonomy does not push the teacher out of his business as the controller of what happens in the classroom, rather it even makes more demands on him to help the learners acquire the skills of independence in learning. As studies, Candy (1991) and Thanasoulas (2000) have shown, rather than being a static product, a state, which is reached once and for all, learner autonomy, is a perennial dynamic process amenable to educational interventions. One of the ways to help learners assume greater control of their learning is by helping them to become aware of and identify the strategies that they already use or could potentially use (Holmes and Ramos, 1991 cited in Thanasoulas (2000)). Also, as Asim (2013) put it, "since learner autonomy deals with self-directed learning on the part of an intrinsically motivated, self-confident and determined learner who is goal-oriented, teachers can encourage learners to follow Tracy (2002) goal-setting principles that can help them to succeed. While stressing the need for learner autonomy, it is instructive to bear in mind research findings to the effect that individual learners differ in their learning habits, interests, needs and motivations and therefore, develop varying degrees of independence throughout their lives.

From the foregone, one can say that the autonomous learners take proactive role in the learning process, generating ideas and availing themselves of learning opportunities rather than simply reacting to various stimuli of the teacher (Thanasoulas, 2000; Boud, 1988; Kohonen, 1992; Knowles, 1975).

The various characteristic attributes associated with autonomous learners may raise doubts in the minds of some to see it as just one of those romantic ideals that cannot match with what is obtainable in our schools. This is because most of those attributes are not easily discernible in our institutions. Greece (2012) observes that some teachers may have problem with this approach because of being ill-prepared or reluctant to wean students away from teacher dependence. Offorma (2002) looks at the problem from the perspective that autonomy is relatively new and comparatively untried making some teachers to feel uneasy with it.

Whatever the case, it is important to "note that autonomy is a process, not a product; one does not become autonomous, one only works towards autonomy. In this respect it is evident that there are things to be achieved by the learner and the means of achieving them, and that autonomy "is learned at least partly through educational experiences (and interventions)" (Candy, 1991, p. 115).

This is the angle this study is emphasizing. We believe that teachers at higher levels of Nigerian education institutions can help their students through their teaching methods to work towards autonomy in learning. According to Asim (2013), educators can adapt their teaching styles in a way that students' ability to manage their own learning increases. The only way to achieve this is by seeing themselves as guides and facilitators of learning rather than purveyors of knowledge and then set the right stage for the learners to explore and acquire skills, knowledge and attitudes intended for them in the curriculum.

\subsection{Theoretical Framework}

The dominant philosophies of knowledge and learning represented by positivism and constructivism provided the basis for this study. Positivism was popular about the 20th century and holds the view that knowledge reflects objective reality (Thanasoulas, 2000). They view the teachers as holders of this objective reality and that learning can only occur through transmission of knowledge from one person to another (Benson \& Voller, 1997). This view led to the traditional classroom that regards the teacher as the purveyors of knowledge and wielders of power while the learners are viewed as passive recipient of the teachers knowledge or even as empty containers to be filled by the teacher. This school of thought is not congruent with the development of learner autonomy which according to Thanasoulas (2000) is "a gradual but radical divorce from conventions and restrictions and is inextricably related to self direction and self evaluation".

On the other hand, constructivism holds that each individual in the learning context constructs his/her own meaning according to his prior experience. Thus, learning is done by the learner through constructing his own meaning from the given text or event(s). This is opposed to the idea that knowledge is something to be internalized or discovered.

According to Candy (1991, p. 270), constructivism leads directly to the proposition that knowledge cannot be taught but only learned (that is constructed), because knowledge is something "build up by the learner". It is obvious that constructivism is in congruent with learner autonomy as it encourages and promotes self-directed learning. We are of the notion that teachers and their instructional practices play important role in whether or not learners achieve autonomy in learning. 


\section{Purpose of the Study}

The purpose of this study was to find out whether lecturers' teaching modes and media utilization in higher education institutions can foster in the students the development of learner autonomy. Specifically, the study set out to achieve the following objectives:

(1) Ascertain the delivery modes of lecturers at higher education level;

(2) Examine the lecturers' utilization of learner-centred modes in curriculum delivery;

(3) Determine the media utilization of lecturers in curriculum delivery.

\section{Research Question}

The following three research questions guided the study:

(1) What are the lecturers' delivery modes in the four faculties of the higher education institution sampled?

(2) To what extent do the sampled lecturers utilize learner- centred methods in their lesson delivery?

(3) What type of electronic media do the lecturers use in delivering their lessons?

\section{Null Hypothesis}

One null hypothesis was tested for the study.

There is no significant difference in the lesson delivery mode of the lecturers from the four faculties sampled?

\section{Method}

\subsection{Area of the Study}

The study was conducted in the University of Uyo. Uyo is the capital city of Akwa Ibom state and has only one federal higher institution where this study was conducted. However, there are many primary and secondary education institutions in Uyo. As the seat of Government, Uyo is inhabited by people from different backgrounds and languages but the formal medium of communication is the English language. Uyo people are of Ibibio stock and speak Ibibio as their mother tongue. The traditions of the people are expressed in Ekpo, Ekpe masquerades and dance. And they are predominantly Christians with a few traditional worshipers and Muslims.

Uyo is located on the map within the coordinates $5.02^{\circ} \mathrm{N}$ and $92^{\circ} \mathrm{E}$; it can be accessed by road, air and telephone. It has a population of 309,573 (2006 census). It is a fast growing city with notable housing estates-Ewet, shelter Afrique and Osongama housings as well as two industrial estates at Aka and Itam. Politically, Uyo Local Government Area is structured into five clans-Uyo, Oku, Offort, Etoi and Ikono with a total of 115 villages. Uyo covers a landmass of 304,769 square kilometers.

\subsection{Design of Study}

A survey design was adopted for the study. A purposive sampling technique was used in selecting four out of the nine faculties in the University of Uyo. A sample size of 400 final year students, consisting of 100 each from the faculties of science, social sciences, Arts and Education participated in the study. The decision to use final year students was borne out of the knowledge that they have been exposed to many lecturers in their departments and so could give accurate information about the lecturers' delivery modes.

\subsection{Instrumentation}

A 25-item questionnaire tagged students' rating of lecturers' use of teaching methods and media in teaching /learning situation developed and validated by the researcher was used in collecting the data. The instrument was constructed on a 4 point rating-scale of very often (4) often (3) seldom (2) Not at all (1). The reliability of the instrument was determined using a comparable sample size of 50 students. The Cronbach's alpha reliability index of 0.73 was established and this was considered adequate for the study.

\subsection{Data Analysis}

Data collected were analyzed using frequency, percentages, and one-way ANOVA. For ease of interpretation of the data, we collapsed the "very often" and "often" columns into one and did the same for "seldom" and "not at all" columns'. Results are presented in tables according to the research questions and the null hypothesis. 


\section{Results}

\subsection{Research Question One: What Are the Lecturers' Delivery Modes?}

Table 1. Faculty by lecturers' delivery modes

\begin{tabular}{cccccc}
\hline & \multicolumn{3}{c}{ Delivery Mode } & \multirow{2}{*}{ Total } \\
\cline { 3 - 5 } & & ISL & IST & PST & \\
\hline \multirow{4}{*}{ Faculty } & Education & 35 & 48 & 17 & 100 \\
& Sciences & 7 & 4 & 89 & 100 \\
& Social Sciences & 8 & 13 & 79 & 100 \\
& Arts & 20 & 10 & 70 & 100 \\
\hline & Total & 70 & 75 & 255 & 400 \\
\hline
\end{tabular}

KEY: PST=Presentation strategies of teaching; IST=Interactive strategies of teaching; ISL=Individualized strategies of learning.

Table 1 shows the delivery model of lecturers from the four faculties used. Lecturers from the Faculty of Education are rated to make more use of IST as shown in the frequencies of 48 as against 35 and 17 for ISL and PST respectively. Those in the sciences are rated to make the most use of PST as reflected in the frequencies of 89, as against 7 and 4 for ISL and IST respectively. Social Science is rated to use PST more than IST and ISL as shown in the frequencies of 79, 13 and 8 respectively. For Arts, the rating is 70 for PST, 20 for ISL and 10 for IST. Apart from education that tended towards IST and ISL, the delivery mode of the lecturers is mostly teacher-centred (PST).

7.2 Research Question 2: To What Extent Do Lecturers Utilize Learner-Centered Methods in Their Lesson Delivery?

Table 2. Extent to which lecturers utilize learner-centered methods in their lesson delivery

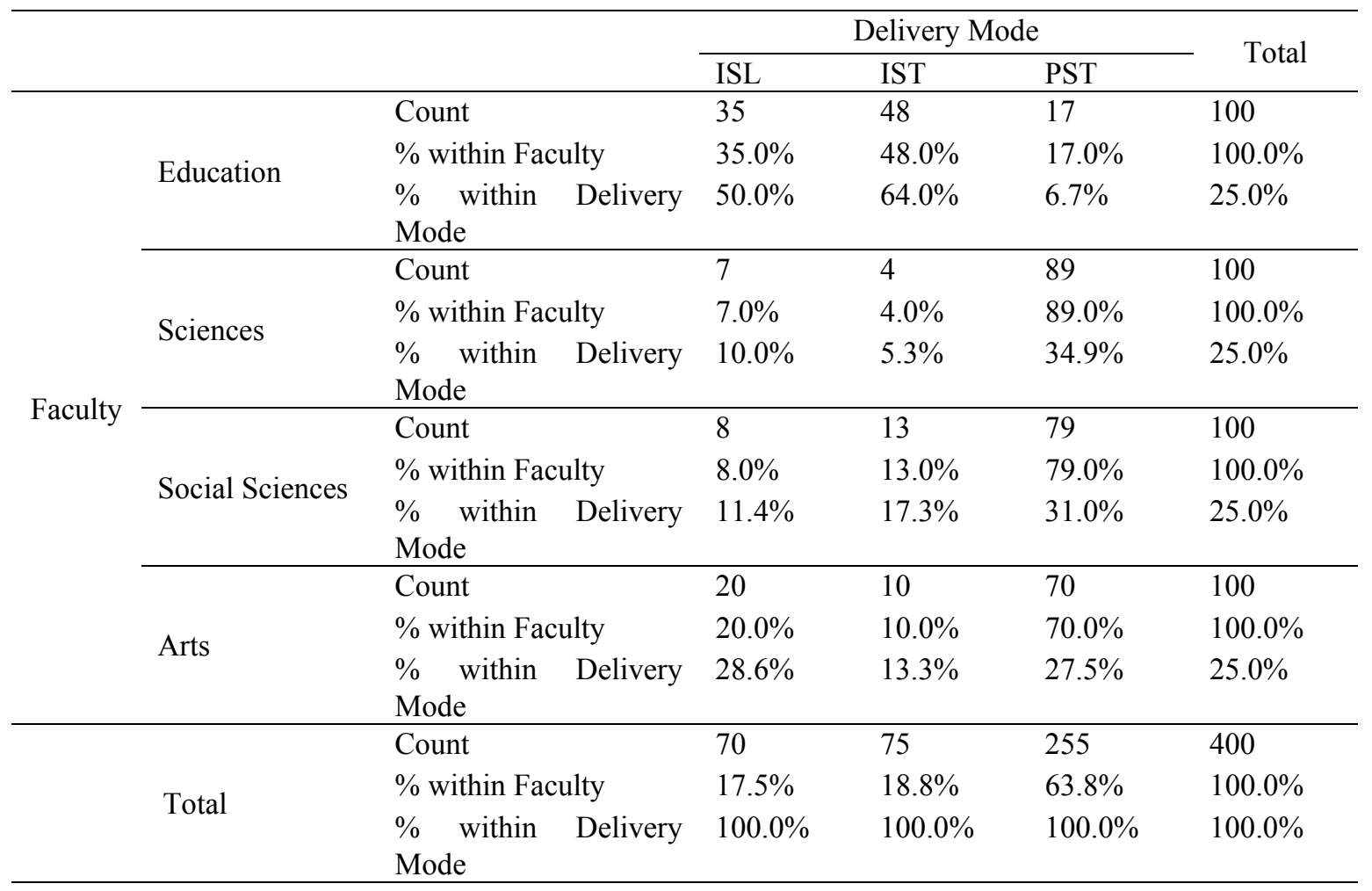


Table 2 shows the extent to which lecturers utilize learner-centred methods in the four faculties sampled. The learner-centred modes are ISL and IST. Education is rated highest with IST of $48 \%$ and ISL, $35 \%$; Arts has $20 \%$ ISL and $10 \%$ IST; social science has $13 \%$ IST and $8 \%$ ISL and science is rated least with $7 \%$ ISL and $4 \%$ IST. Thus, lecturers utilized learner-centred modes to a least extent.

7.3 Research Question 3: What Type of Electronic Media Do the Lecturers Use in Delivering Their Lessons?

Table 3. Type and extent of Electronic Media Lecturers use in their lesson delivery

\begin{tabular}{|c|c|c|c|c|c|}
\hline & \multicolumn{2}{|c|}{ Electronic Media } & \multirow[t]{2}{*}{ Total } \\
\hline & & & LLM & HLM & \\
\hline \multirow{15}{*}{ Faculty } & \multirow{3}{*}{ Education } & Count & 69 & 31 & 100 \\
\hline & & $\%$ within Faculty & $69.0 \%$ & $31.0 \%$ & $100.0 \%$ \\
\hline & & $\begin{array}{l}\% \text { within Electronic } \\
\text { Media }\end{array}$ & $25.8 \%$ & $23.3 \%$ & $25.0 \%$ \\
\hline & \multirow{3}{*}{ Sciences } & Count & 75 & 25 & 100 \\
\hline & & $\%$ within Faculty & $75.0 \%$ & $25.0 \%$ & $100.0 \%$ \\
\hline & & $\begin{array}{l}\% \text { within Electronic } \\
\text { Media }\end{array}$ & $28.1 \%$ & $18.8 \%$ & $25.0 \%$ \\
\hline & \multirow{3}{*}{ Social Sciences } & Count & 58 & 42 & 100 \\
\hline & & $\%$ within Faculty & $58.0 \%$ & $42.0 \%$ & $100.0 \%$ \\
\hline & & $\begin{array}{l}\% \text { within Electronic } \\
\text { Media }\end{array}$ & $21.7 \%$ & $31.6 \%$ & $25.0 \%$ \\
\hline & \multirow{3}{*}{ Arts } & Count & 65 & 35 & 100 \\
\hline & & $\%$ within Faculty & $65.0 \%$ & $35.0 \%$ & $100.0 \%$ \\
\hline & & $\begin{array}{l}\% \text { within Electronic } \\
\text { Media }\end{array}$ & $24.3 \%$ & $26.3 \%$ & $25.0 \%$ \\
\hline & \multirow{3}{*}{ Total } & Count & 267 & 133 & 400 \\
\hline & & $\%$ within Faculty & $66.8 \%$ & $33.3 \%$ & $100.0 \%$ \\
\hline & & $\begin{array}{l}\% \text { within Electronic } \\
\text { Media }\end{array}$ & $100.0 \%$ & $100.0 \%$ & $100.0 \%$ \\
\hline
\end{tabular}

Key $=\mathrm{LLM}=$ low level media; HLM=high level media.

Table 3 shows the type and extent of media utilized by lecturers in their lesson delivery. Science is rated the highest user of LLM 75\% and the least of HLM (25\%). This is followed by Education with 69\% LLM and 31\% HLM; the next is Arts with 65\% LLM and 35\% HLM while social science has 58\% LLM and 42 HLM. Thus, the lecturers used more of low level media in delivering their lecturers.

7.4 Test of Hypothesis: There Is No Significant Difference in the Lesson Delivery Modes of the Lecturers from the Four Faculties Sampled

Table 4. Analysis of variance for the difference in lesson delivery modes of lecturers from the four sampled faculties

\begin{tabular}{cccccc}
\hline Delivery Mode & $\begin{array}{c}\text { Sum of } \\
\text { Squares }\end{array}$ & df & Mean Square & F & Sig. \\
\hline Between Groups & 60.327 & 3 & 20.109 & $44.460^{*}$ & .000 \\
Within Groups & 179.110 & 396 & .452 & & \\
Total & 239.437 & 399 & & & \\
\hline
\end{tabular}

*Significant at $.05 ;$ Critical $\mathrm{F}=2.65 ; \mathrm{N}=400$. 
Table 4 show Fcal of 44.46 which is greater than critical $F=2.65$ at .05 alpha level. Based on this the null hypothesis was rejected. This means that there is a significant difference in the lesson delivery modes of lecturers from the four faculties. In order to know where the differences occurred, a multiple comparison using LSD was done and the result is shown in Table 5.

Table 5. Multiple Comparisons using LSD for lesson delivery modes of lecturers from four faculties

\begin{tabular}{lllll}
\hline (I) Faculty & (J) Faculty & $\begin{array}{l}\text { Mean Difference } \\
\text { (I-J) }\end{array}$ & Std. Error & Sig. \\
\hline \multirow{3}{*}{ Education } & Sciences & $-1.00000^{*}$ & .09511 & .000 \\
& Social Sciences & $-.89000^{*}$ & .09511 & .000 \\
& Arts & $-.68000^{*}$ & .09511 & .000 \\
\hline \multirow{3}{*}{ Sciences } & Education & $1.00000^{*}$ & .09511 & .000 \\
& Social Sciences & .11000 & .09511 & .248 \\
& Arts & $.32000^{*}$ & .09511 & .001 \\
\hline \multirow{3}{*}{ Social Sciences } & Education & $.89000^{*}$ & .09511 & .000 \\
& Sciences & -.11000 & .09511 & .248 \\
& Arts & $.21000^{*}$ & .09511 & .028 \\
\hline \multirow{3}{*}{ Arts } & Education & $.68000^{*}$ & .09511 & .000 \\
& Sciences & $-.32000^{*}$ & .09511 & .001 \\
\hline
\end{tabular}

* The mean difference is significant at the .05 level.

Table 5 shows that education was significantly different from science, social sciences and Arts; Science was significantly different from Education and Arts but not with Social Sciences. Social Science was significantly different from Education and Arts but not with the Sciences, whereas, Arts was significantly different from education, Science and Social Science.

\section{Discussion of Findings}

\subsection{Curriculum Delivery Mode of Lecturers and Learner Autonomy}

The findings in Tables 1 and 2 show that lecturers' delivery modes tend towards teacher-centredness as represented by PST except for faculty of education which had higher percentage for learner centered modes represented by ISL and IST. This finding corroborates earlier studies (Obanya, 2007; Igbokwe, 2010; Uloh-Bethels, 2013). These researchers asserted that the traditional methods of delivering curriculum where the teacher dominated the class activities still prevail in our higher institutions. The predominant teacher-centred modes indicate that the teachers are still influenced by the long age notion that they are purveyors of knowledge and feel insecure in weaning the learners to take charge of their learning (Benson \& Voller, 1998).

The finding that Faculty of education is rated highest in the use of learner-centered approaches (ISL $35 \%$ and IST 48\%) than others may be attributed to their professional background as teachers. They know the theories of instruction and psychology of learning and may have applied them in delivering the curriculum.

\subsection{Media Utilization and Learner Autonomy}

The results in Table 3 indicate that lecturers in the four faculties sampled make more use of low level media in their lesson delivery. The non-utilization of high level media further supports the findings in Tables 1 and 2 that lecturers are still not willing to wean the learners from teacher dependence. Their lessons are dominated by talk and chalk especially is this noticeable in the Faculty of science with the least percentage of HLM (25\%). The HLM are the resources that can facilitate ISL and IST and connect the learners to the outside world and enable them to take charge of their learning. The teachers in the sampled faculties seem not to have yet keyed into the new changes to the curriculum that emphasizes learner autonomy (Thanasoulas, 2000; Materus, 2007). We can also attribute the lack of utilization of HLM to teachers' incompetence with the new media technologies and/ or lack of availability of these resources. 


\section{Conclusions}

From the findings of this study, we can safely conclude that lecturers' utilization of teaching modes and media are not compatible with the development of learner autonomy which is highly desired for the production of quality manpower for the nation. Lecturers still find it difficult to wean their students from depending on them for success in school work. Most of them are still operating teacher-centred methods especially in the science faculty. Their lack of media utilization may be due to incompetence or/ and inaccessibility of those resources.

\section{Recommendations}

There is need for training to re-orient the lecturers to the changes in the curriculum which has necessitated the shift in power towards more learner-centred approaches.

There is need to train them on the new technological developments that ease their work and achieve more results. Lecturers need to see themselves more as facilitators of learning than purveyors of knowledge and should wean learners of dependence on their lecture notes.

Modern media technologies that facilitate effective curriculum delivery should be made available in higher education institutions for both students' and lecturers' use to achieve the goals of higher education in the country.

\section{References}

Akinmusuru, J. O. (n.d.). The Curriculum as a living document for achieving education for sustainable development. Retrieved from http://www.gc.aau.org/papers/joe_o_\% 20 Akimusuru-full20.pdf

Asim, A. E. (2013). Learner autonomy. Journal of curriculum and Instruction, 9(1), 17-27.

Barnes, D. (1976). From Communication to Curriculum. Harmondsworth: Penguin.

Benson, P., \& Voller, P. (1997). Autonomy and Independence in Language Learning. London: Longman.

Boud, D. (Ed.). (1988). Developing Student Autonomy in Learning. New York: Kogan Press.

Brown, H. D. (1987). Principles of Language Learning and Teaching. Englewood Cliffs, JC: Prentice Hall.

Candy, P. C. (1991). Self-direction for Lifelong Learning. California: Jossey-Bass.

Egbe, C. I., \& Uloh-Bethels, A. C. (2013). Strategies for promoting learner autonomy in English language education curriculum delivery in south east Nigerian universities. Journal of Curriculum and Instruction, $9(2), 43-51$.

Falayajo, W. (2004). Educational Practices in Nigeria: The gap between the status quo and ideal. University of Ibadan. Valedictory Lecture.

Federal Republic of Nigeria. (2004). National Policy on Education. Yaba: NERDC Press.

Greece, D. T. (2012). What is learner autonomy and how can it be fostered? Retrieved from http://www.telus.net/lingisticsissues/learnerautonomy/html

Holec, H. (1981). Autonomy in Foreign Language Learning. Oxford: OUP.

Igbokwe, U. L. (2010). Reforming the classrooms for vision 20:20 20. In N. Onyegegbu, \& U. Eze (Eds.), Teacher preparation and the vision 20-20:20 in Nigeria. Enugu: Timex.

Knowles, M. S. (1975). Self-directed Learning. New York: Association Press.

Knowles, M. S. (1980). The Modern Practice of Adult Education: From Pedagogy to Andragogy. Chicago: Follett.

Knowles, M. S. (1983a). Andragogy: An Emerging Technology for Adult Learning. In M. Tight (Ed.), Adult Learning and Education. London: Croom Helm.

Kohonen, V. (1992). Experiential language learning: Second language learning as cooperative learner education. In D. Nunan (Ed.), Collaborative Language Learning and Teaching (pp. 14-39).

Lier, van L. (1996). Interaction in the Language Curriculum. Awareness, Autonomy and Authenticity. USA: Longman.

Little, D. (1991). Learner Autonomy. 1: Definitions, Issues and Problems. Dublin: Authentik. Retrieved from http://www.llas.ac.uk/resources/gpg/1409

Macdougall, M. (2008). Ten tips for promoting autonomous learning and effective engagement in the teaching of 
statistics to undergraduate medical students involved in short-term research projects. Journal of Applied Quantitative methods, 3(3), 223-240. $\quad$ Retrieved from http://www.academia.edu/613505/MacDougall_M_2008_

Manoharan, P. K. (2009). Higher Edcation. New Delhi: A. P. H. Publishing Corporation. Retrieved from http://www.waterstones.com/waterstonesweb/products/p-+k-+manoharan/higher+education/9613095/

Materu, P. (2007). Higher Education Quality Assurance in Sub-Saharan Africa, Status, Challenges, Opportunities, and Promising Practices. Washington DC: World Bank Working Paper No.124. http://dx.doi.org/10.1596/978-0-8213-7272-2

Obanya, P. A. (2007). Thinking and talking education. Ibadan: Evans and Brothers Ltd.

Obanya, P. A. I. (1999). Higher education for an emergent Nigeria. University of Ibadan 50th anniversary lecture, Faculty of education, Ibadan: Heinemann.

Offorma, G. C. (2009). Curriculum implementation in distance learning. In U. M. O. Ivowi et al. (Eds.), Curriculum theory and Practice. Abuja: Top Goddy Nig. Ltd.

Osam, O. E. (2013). Teacher quality: The key to effective curriculum delivery at higher education level in Nigeria. Journal of Curriculum and Instruction, 9(2), 18-22.

Sheerin, S. (1991). State of the art: Self-access. Language Teaching, 24(3), 153-157. http://dx.doi.org/10.1017/S0261444800006315

Thanasoulas, D. (2000). What is learner Autonomy and how can it be fostered? Retrieved from http://itesly.org/Artcles/Thanasoulas-Autonomy.html visited13/10/12

Tracy, B. (2002). Eat that frog-21 great ways to stop procrastination and get more done in less time. USA: Berret-koehler publishers.

Udofot, M. A. (2006). The roles of Nigerian Universities teachers in national development. In U. Etuk (Ed.), University Education and Sustainable Development (pp. 9-21). Uyo: Minder International Publishers.

\section{Copyrights}

Copyright for this article is retained by the author(s), with first publication rights granted to the journal.

This is an open-access article distributed under the terms and conditions of the Creative Commons Attribution license (http://creativecommons.org/licenses/by/3.0/). 